Article

\title{
Vox España and Alternative für Deutschland: Propagating the Crisis of National Identity
}

\section{Robert Gould}

Institute of European, Eurasian and Russian Studies, Carleton University, Ottawa, ON K1S 5B6, Canada; Robert.Gould@carleton.ca

Received: 19 August 2019; Accepted: 25 November 2019; Published: 29 November 2019

\begin{abstract}
This paper contains a comparative analysis of the presentation of the national identity of Spain and Germany by the far-right populist parties Vox España and Alternative für Deutschland. It shows how each party views national identity as being in a serious crisis arising from the betrayal by old-line parties which has led to the increased influence of the EU, the consequent reduction of national sovereignty, a deleterious impact on their own and on European culture, and a harmful influence on the family. The parties repudiate many of the provisions of the EU treaties. They are equally opposed to the presence of Islam in Christian Europe, viewing it as a menace to values shared by all European nations. These analyses lead to an examination of the performance of crisis by means of deliberate provocation and the use of electronic media. It shows how these parties from very different parts of Europe share remarkably close positions and use the technological achievements of the twenty-first century to attack the late-twentieth-century political and social achievements of the European Union in order to replace them with the nineteenth-century idea of the distinct ethno-cultural nation fully sovereign in its own nation-state.
\end{abstract}

Keywords: Alternative für Deutschland; Vox España; national identity; nationalism; nativism; crisis; Islamophobia; European Union

\section{Introduction}

The impacts of the turbulent years in European life and politics which began with the Great Recession starting in 2008 have been and are still being felt in many areas of social and political life and in many countries of the European Union. This is the background to this paper which focusses on related questions of national identity in Spain and Germany as defined and propagated by, respectively, Vox España (Vox) and Alternative für Deutschland (AfD). It is to be noted from the beginning that each of these new parties contains the name of the respective country (with all the accompanying rational and emotional overtones) plus the suggestion of something new: The first is to be the "voice" of a Spain not otherwise heard, and the second asserted that there did exist an alternative to Angela Merkel's Euro bailout (Jahn 2013); it also continues to assert that there is an alternative to existing policies and practices deemed harmful to national identity. These two parties with strong nationalistic or nativist tendencies emerged in EU member states marked, until recently, by a stable party system in which each existing party broadly viewed national identity similarly (open, liberal, EU-oriented) while differing and competing in the areas of social, European, foreign and economic policies, each proclaiming its link to country. That the positions of the two new parties exercise a noticeable attraction for voters emerges quite clearly from recent election results: In the elections of 2 December 2018 for the parliament of the autonomous community of Andalusia Vox obtained $10.97 \%$ of the vote and 12 seats. Subsequently, in the general election of 28 April 2019 , it won $10.26 \%$ of the votes and 24 seats in the Congreso de los Diputados, though none in the Senate. By the date of the Spanish elections AfD 
was represented in the parliaments of all sixteen states of Germany with support ranging from 5.9\% (Schleswig-Holstein) to $24.3 \%$ (Saxony-Anhalt), as well as in the Bundestag, where it had 94 members and nationally achieved $12.6 \%$ of the Zweitstimmen ${ }^{1}$.

In the slightly later Spanish election cycle of 26 May 2019 with elections for all municipal councils, for the parliaments of twelve of the seventeen comunidades autónomas and for the two autonomous cities of Melilla and Ceuta on the North-African coast, Vox also presented candidates. It published a separate manifesto for the EP election and a joint one for the elections for the parliaments of the autonomous communities. The party succeeded in electing representatives in seven of the twelve communities where elections were held. It obtained $6.2 \%$ of the votes for the European Parliament, which translated into three representatives. Most recently, in the repeat of the national elections on 10 November 2019, Vox obtained $15.1 \%$ of the vote (an increase of 50\% over the April result) and with 52 seats more than double its representation in the Congreso de los Diputados.

These two parties have irrupted onto the political scene in their respective countries where they are playing a role and have achieved a visibility and audibility beyond what their numbers might suggest. With counterparts in Austria, Hungary, Italy, the Netherlands, the UK, etc., many of which existed years before AfD and Vox, they are part both of a Europe-wide populist, nationalist and nativist phenomenon, representing also a real challenge to the European Union. Given that Vox España has emerged so very recently, and Alternative für Deutschland only a very few years earlier (see below), and that the question of national identity is at the core of their public positions, it is revealing to compare in a detailed manner the parallels between the two parties in this central area. This is being done in order to gain an appreciation of just what they stand for, particularly as there is relatively little in English on AfD $^{2}$ and only (Turnbull-Dugarte 2019; Gould 2019) on Vox, both of which limit themselves largely or exclusively to the Andalusian elections of December 2018.

\section{Outline and Methodology}

For the purposes of this paper and its analyses the definition of national identity to be used is that of the project at the Universidad Pablo de Olavide in Seville, Nacionalismo de estado de democracias multinacionales: El impacto de la Gran Recesión sobre la identidad nacional: "We define national identity as the subjective feeling of belonging to a territorially-defined political community within which the inhabitants feel that they share certain characteristics or common elements"3.

In undertaking a point-by-point qualitative analysis of official party documents (as well as a reference to an important speech by Vox's leader, Santiago Abascal Conde, at a mass meeting in Madrid), the comparison will show how very different parts of the European continent which achieved stable democratic government after a period of extreme-right/fascist rule have now produced and are propagating very similar right-wing views on national identity-a term which includes among other topics culture, the family, the relationship to Europe, and immigration. In order to gain a full appreciation of the proximity of the two parties it is important to lay out their positions in some detail.

The corpus of material for analysis are publicly available documents of each of the two parties: For Vox the Manifiesto fundacional (Vox España 2014) and 100 medidas para una España viva (Vox España 2018), plus the separate manifestos for the EP elections of 2019, Programa electoral para las elecciones europeas de 2019 (Vox España EP 2019), and the joint manifesto for those autonomías re-electing their parliament in 2019 (Vox España EA 2019). For AfD the manifestos for analysis are those for the important series of elections at the national, regional, and European levels in 2017, 2018, and 2019 (AfD 2017; AfD Bavaria 2018; AfD Hesse 2018; AfD EP 2019). Reference will also

1 Germany's electoral system is characterised by the fact that voters each have two votes: The first is for an individual candidate in the voter's electoral district, and the second, the Zweitstimme, is for a party list in the voter's state.

However, for a very detailed analysis of AfD manifestos, see (Gould 2018).

Definimos la identidad nacional como el sentimiento subjetivo de pertenencia a una comunidad política, definida territorialmente, con la que uno imagina que comparte algunos rasgos o elementos comunes. 
be made to the AfD manifestos for state elections in Lower Saxony, North Rhine-Westphalia, the Saarland, and Schleswig Holstein. The importance of these documents is that that they are (a) issued by the parties themselves and thus there can be no claim of misrepresentation by journalists or others, (b) they are definitive, and (c) they stand at the beginning of the important communication chain for both national-level or regional-level communications (radio and television reporting) and electoral-district-level communication (e.g., person-to-person), plus the increasing role of social media communication. As such, these documents are absolutely fundamental. They represent the state of the parties' thinking at the time of the election in question.

Following the critical discourse analysis example of the seminal work Zur diskursiven Konstruktion nationaler Identität (Wodak et al. 1998), the approach is qualitative, concentrating on identifying what the parties present as fundamental characteristics of their respective nation and how they do it: This includes the linguistic construction of a shared culture (both national and European) linking past, present and future, and also the nature of the national state as the present and future framework within which the nation exists, to which it gives (or should give) form, and which in turn moulds or accepts the nation itself. In this way it will show the pivotal role of language in creating "opaque as well as structural relationships of dominance, discrimination, power and control" (Wodak and Meyer 2009, p. 10). The paper will undertake this investigation of national identity as propagated by what are stipulated to be populist parties (Bebnowski 2015; Turnbull-Dugarte 2019; Häusler 2019).

After background information on the two parties, Sections 3 and 4 will consider the linked views of national identity (including the national state) and crisis which the parties are propagating in the public political sphere in each country. In this respect, the two parties demonstrate a remarkable range of similarities which this paper will explore together. However, there is one significant difference: Their attitude towards the national state as it exists in their respective territory.

In Section 5 the paper will take a further step. It will argue that the parties' presentations are not simply descriptive but are also dynamic and amount to a performance of identity crisis. This paper will point to Vox's and AfD's allegations of the failure of old-line parties to protect national identity, thus in their view engendering a crisis. Following Taggart (2000), Moffitt $(2014,2016)$ argues for the key role of crisis in understanding contemporary populism. The significance and function of performance of crisis by contemporary populist parties as outlined by Moffitt is that it is an important device employed by them to gain and maintain electoral success. The application of his six-step model of crisis performance will permit the paper to establish a further link between these two comparable parties situated in very distinct countries. At the same time, it will show how a 'problem' area can be transformed into a threatening existential force of long duration.

In the Conclusion the paper will briefly consider the technological and human environments, as well as the constellation of nineteenth-century, twentieth-century, and twenty-first-century forces which have come together in Vox España and Alternative für Deutschland to promote their performance and propagation of crisis.

\section{Background}

\section{1. $V o x$}

Preceded by the short-lived Fuerza Nueva and the equally short-lived and regionally-focused parties Plataforma per Catalunya and Espanya 2000 (Casals 2016), and later supported electorally by such minor right-wing parties as Alternativa Española or Comunión Tradicionalista Carlista, Vox was founded in a rather disorganised manner in December 2013 (Kadner 2014) and became active for the 2014 EP elections ( 2018) $)^{4}$. Until the Andalusia vote in December 2018 (discussed by (Ortiz 2019) in this

4 The normal practice of the publishing house behind this work, Ikusle, is that it does not provide the names of authors, possibly because it is linked to the Basque nationalist movement Izquierda Abertzale (previously close to ETA). Similarly, it 
issue) it had been, at best, a marginal force in Spanish politics with just four mayors (two of whom had switched parties) of tiny municipalities and twenty-two municipal councillors. In the 2015 municipal elections it had obtained a total of only slightly over 51,000 votes, i.e., $0.25 \%$ of all the votes cast (El Confidencial 2015). The party defines its fundamental positions in two position papers: Manifiesto fundacional (Vox España 2014), and 100 medidas para una España viva (approximately: One Hundred Measures to promote Spanish Life and Values) (Vox España 2018).

Its position on the right of the political spectrum emerges clearly in statements given in Vox España, la tentación populista española ( 2018, passim), and explicitly in the positions outlined by (Piñar Pinedo 2015) in which he categorises Vox as filling the vacuum on the right of Spanish politics and as holding fundamental views characteristic of the Right including sharp criticism of the EU. However, it is to be noted that these ideas and others fundamental for Vox did not emerge with the creation of the party. The book by (Abascal Conde and Sánchez 2008) contains already a great deal of what are now the official positions of Vox.

Given that Vox has emerged so recently as a force in Spanish politics, analyses by scholars are rare. However, those to be found in the webliography of different print and web publications by Casals merit particular attention (Casals 2019) ${ }^{5}$. In light of the fact that it is a truth universally acknowledged, including by Abascal himself (see above and Abascal 2015), that Vox is a party of the right, the questions in the various analyses which exist by other scholars on the nature of Vox have been published in the daily press and so far revolve around the matter of whether it should be categorised as a right-wing party, a far-right party, or as on the radical-right, and also whether its language might be considered (or not) neo-fascist (Anduiza 2018; Acha 2019a, 2019b).

A tremendous opportunity was provided for Vox by the surge in Catalan separatism, which the party seized on. This coincided with the political dissatisfaction caused when the new "Statute of Autonomy" (i.e., the quasi-constitution of Catalonia) which had been accepted by a large majority of Catalans in a referendum in 2006, was challenged in the Constitutional Court by the PP and some autonomous communities. The Court's largely negative judgement, finally released in 2010, unleashed a significant rise in popular support for independence, and the organisation of the independence referendum of 1 October 2017, which was accompanied by civil disturbances (Humlebæk 2015; Lecours 2018).

Since the elections preceding and following the referendum on 1 October 2017 the "Catalan question" was never far from media attention. From 12 February 2019 when it began, i.e., during the pre-campaign and the campaigns for all the elections of April and May 2019, the trial in the Tribunal Supremo in Madrid of 12 persons facing various serious criminal charges relating to the planning and holding of the referendum was heavily mediatised. Additionally, in the trial Vox has increased the visibility of itself and its position by becoming a civil party (acusación popular) to the indictments. These facts and media attention concord with the starting point of the policy statement 100 medidas para la España viva, which takes a hard line in order to deal resolutely with the continuing Catalan crisis.

In addition to all the above, the continuing revelations of widespread political and commercial corruption (put by (Gómez Reino and Llamares 2019, p. 296) at nearly 2000 cases by 2014, and certainly higher since that date) suggested that the problem of corruption was far from settled. Vox España is doing the same thing as AfD in Germany: In a moment of political failure and fluidity it has positioned itself as in touch with and expressing the real needs of the Spanish people and both willing and able to dominate and correct the definition of national identity in an unstable world.

provides no information on the place of publication. I am grateful to Pablo Ortiz Barquero of the Universidad Pablo de Olavide in Seville for this information.

5 Information received from Pablo Ortiz Barquero of the Universidad Pablo de Olavide is gratefully acknowledged. 


\subsection{AfD}

Founded in 2013, and with members elected to the European Parliament and to the state parliaments of Saxony, Brandenburg, and Thuringia in 2014 (in addition to a number of municipal and Kreis councils), the AfD achieved parliamentary representation four years earlier than Vox. This means that (as of 2019) in contrast to Vox there is already a considerable body of scholarly research on AfD. The party's emergence and metamorphosis has been outlined by, for example, (Decker 2016; Lewandowsky 2016; Lehmann and Matthieß 2017; Jesse 2019). The most detailed account is to be found in (Butterwegge et al. 2018, Chapter: "Entstehung und Entwicklung der AfD bis zur Gegenwart") which also provides information on other and earlier populist parties in Europe with very similar discourse strategies and concepts to those to be outlined below for AfD. Within the development process of the party an important factor is the role played by the massive influx of refugees (at least 800,000) in 2015 (Arzheimer and Berning 2019; Geiges 2018). The party is also the farthest right of any party on the parliamentary spectrum in Germany, which has naturally given rise to the Federal Office for the Protection of the Constitution's (Bundesverfassungsschutz) placing it under observation. Presentations and analyses of its radicalisation and/or positions are to be found in, for example, (Gould 2018 ; Zick et al. 2019). These considerations inevitably lead to the topic of populism in relation to AfD: See (Lees 2018; Häusler 2019). They equally lead to questions about the party's electorate, particularly as relating to the rejection of refugees (Hambauer and Mays 2018; Lengfeld and Dilger 2018). There is, however, some discussion around the question of whether persons at the lower end of the social scale are more inclined or not to vote for AfD (Lengfeld 2017; Lux 2018) or whether they were drawn from the same classes of voters as the existing parties (Hansen and Olsen 2019).

In the case of $\mathrm{AfD}$, a similar opportunity to that provided to Vox by the surge of regional separatism in Catalonia was the arrival in Germany in 2015 of at least 800,000 refugees from Moslem countries. It accelerated the move by the AfD away from its origins in the financial crisis as an anti-Euro party towards a more nationalist stance more immediately understandable and appreciated by a wider voting public, enabling the party to point to the danger the refugees represented for national identity.

The evidence above that Abascal's positions on fundamental points concerning Spanish identity significantly pre-date the party, plus the information on Islamophobia and anti-Islamic discourses at various levels of German society (see above and Sarrazin 2010) in the 1990s and 2000s, indicate that any 'Bannon effect' arising from his networking in Europe in 2018/2019, much discussed in the press (Die Welt 2019; Junquera 2018; Pérez Oliva 2018), and deliberately provocative interviews (Verdú 2019), is limited to the promotion of well-established and already-existing views on Muslims, immigration, the EU, the nation, etc., and does not involve the creation of these views. (Junquera 2018) and Verdú's interview with Bannon (Verdú 2019) indicate the establishment of contacts between Bannon and Vox; for contacts between Bannon and AfD, see (Serrau 2019).

\section{The Nation}

\subsection{The Nation and Its National State}

Each party views Spain or Germany, as the case may be, as the present and future framework for the existence and evolution of its respective nation. Consequently, it is both relevant and important to consider the attitude to the state and the fit (or otherwise) between this essential framework and the nation which inhabits it.

In the case of each country, the fundamental structure of the national state is federal. In Germany this is not contested by any party or at any level. In Spain, on the other hand, the term "federal"

6 To save space and avoid repetition frequent reference will be made to this long analysis of the AfD election manifestos for the 2107 federal election and for the 2017 state elections in Lower Saxony, North Rhine-Westphalia, the Saarland, and Schleswig-Holstein. 
is strictly avoided. However, with significant areas of governmental activity such as health-care, social policy, policing, local government, language, education, some areas of taxation, certain levels of the administration of justice, cultural affairs, agriculture, environment, heritage affairs being the responsibility (though in some cases shared with the central government) of the elected parliament and cabinet of each of the seventeen 'autonomous communities' whose existence is guaranteed in the Constitution (plus also the autonomous cities of Melilla and Ceuta on the North African coast), it is not unreasonable to think of the structure as federal in fact and form, if not in terminology (Baglioni 2013). This federal or quasi-federal political structure is the home to the respective Volk and nación, each of which is acknowledged to be an ethno-cultural entity (see below). However, it will also be outlined below how Vox consistently attacks the current political form of Spain as fundamentally in contradiction to its conception of the unitary identity of the Spanish nation and consequently as deeply harmful to this unity and to the unity of the state. The two parties differ fundamentally in their attitudes to the political structure of the nation state.

\subsection{AfD}

In the AfD manifestos for the elections in Germany in 2017 (for the Bundestag and for the state parliaments of Lower Saxony, North Rhine-Westphalia, the Saarland, and Schleswig-Holstein), and then also in 2018 (state elections in Bavaria and Hesse), there is nowhere any indication of tension or contradiction between the federal and state levels of government (Gould 2018). Additionally, regional culture and identity are nested within a shared German identity without there being any contradiction between the two (AfD 2017, 1.1). These positions were maintained in the manifestos for the 2018 state elections in Bavaria (AfD Bavaria 2018) and Hesse (AfD Hesse 2018). The outcomes of these elections led to the AfD being represented in the parliaments of all individual states, in addition to the Bundestag.

The AfD provides no reasons for its total satisfaction with the federal structure of the German national state as outlined in the Constitution. It is not an issue of any sort, and one may conclude that it is not in any contradiction with the party's conception of the nation and national identity. Acknowledged regional differences are unproblematic, accommodated by the federal structure, and, clearly, for the AfD this structure in no way diminishes the feeling of belonging to the national group, summarised in the expression "unity in diversity" (AfD 2017, 1.1), nor does it undermine its notion of popular sovereignty. In addition, for the AfD adherence to, and realisation of, the often-repeated fundamental constitutional concept "freiheitliche demokratische Grundordnung"|"free and democratic society", are also a characteristic of German identity (Gould 2018).

On the other hand, for AfD the importance of popular sovereignty and the imposition of restrictions on professional politicians are such that the first chapter, "Defence of Democracy in Germany", of the 2017 federal election manifesto (AfD 2017) contains proposals for significant changes in the functioning of the state: Following the Swiss pattern, the voters are to be given the power to amend or repeal acts of the Bundestag, and to propose and pass legislation via the use of referenda. In addition, constitutional changes should be made only with popular support in the form of a referendum; the Chancellor, state premiers, ministers, and parlamentarische Staatssekretäre (parliamentary undersecretaries) may no longer be members of the appropriate legislative body; the President should be chosen in a vote of the people; the Chancellor should serve for a maximum of two electoral terms, and members for no more than four.

\subsection{Vox}

The positions of Vox España on the structure of the Spanish state are outlined in the two source documents mentioned above: 100 medidas para la España viva (Vox España 2018) and Manifiesto fundacional (Vox España 2014). Despite the linguistic and cultural diversity of Spain, this state is the home to the Spanish Nation which is "indissoluble in its unity", and of which the national sovereignty is vested in "the totality of the Spanish people" (Vox España 2014). At the same time, Vox states its awareness of the great human diversity of Spain— "the historical and cultural plurality of our Nation" 
(Vox España 2014, p. 5) and "the cultural, linguistic, legal and insular facets and facts characteristic of our country" (Vox España 2014, p. 6).

It is the two factors of the linguistic and cultural diversity on the one hand and the "indissoluble unity of the Spanish people", which, taken together with the desire to abolish the quasi-federal structure of Spain and create a unitary state, make the current and continuing question of Catalan separatism so acute and have led to the opening section of 100 medidas having the title "Spain, Unity and Sovereignty".

On the failure of the Spanish "State of the Autonomous Communities", the Estado de las Autonomías, Vox states forcefully its rejection of the status quo and the reasons for its rejection in the following terms:

The Spanish State of Autonomous Communities has not fulfilled the goals for which it was created and its cost has reached alarming proportions. The political decentralisation which has reached extremes scarcely compatible with the Constitution, far from pacifying the national question in Catalonia and the Basque Country, has aggravated the centrifugal tensions and has pushed Spain to the verge of disintegration. (Vox España 2014, p. 3).

Spain is in a crisis situation which can only be solved in the following way:

Transformation of the Spanish State of Autonomous Communities to a unitary Spanish State founded on the rule of law and promoting equality and solidarity in the place of privileges and division. A single government and a single parliament for the whole of Spain. (Vox España 2018, Item 6).

These are views which are reiterated and emphasised in the manifesto for the elections to the autonomous communities (Vox España EA 2019) where the rejection of the communities is expressed very forcefully. The position in the documents (100 medidas, Manifiesto fundacional, the Programa electoral para las elecciones europeas de 2019 (Vox España EP 2019), and the Vistalegre speech, which formed an overture to the coming election campaigns of 2019 (Abascal 2018), is that Spain and the Spanish people precede, and possess a separate and well-developed existence from, the state created by the Constitution of 1978: That is, Spanish national identity is, above all, ethno-cultural and pre-constitutional. Consequently, Spanish national identity is distinct also from the Estado de las Autonomias. Given the hostility to that particular organisational form, this becomes a loaded and hostile term to the point that it is described as "a slow suicide" and has pushed the country to the verge of disintegration (Vox España 2014, p. 3). For these reasons the political community to which individuals are invited, or expected, to identify is above all a Spain constituted by notions of the Spanish past and its heroes, its high culture and its popular cultures, its unity and territorial integrity, its imperial and European deeds (including saving Europe and European civilisation from Islam: See below), its dignidad, honor, valor handed down from past generations, its destino, and its Christianity [i.e., Catholicism] (Abascal 2018). The appeal is to a quasi-sacralised 'Spain' thusly constituted (España is mentioned 69 times) and not to constitutional values: Constitución is never mentioned in the Vistalegre speech. For Vox the only political community with which to identify and where citizens should feel they belong is Spain as a whole; the autonomous communities diminish or destroy "the subjective feeling of belonging to the political community [of Spain]".

The contrast here is that between the AfD's satisfaction with the federal structure of its political community and Vox's total dissatisfaction with the form of its political community. It is a contrast relating in both cases to an awareness of real sub-national differences and their place within the whole, but to an entirely different attitude towards such differences: After the achievement of a German nation state, whether the unification of 1871 or the unification of 1990 following the forced split into two states after WWII, regional differences are accepted as falling within the broader definition of "German" and are not considered threatening. 
In Spain, there is a difficult terrain for the negotiation of a national identity which is purely "Spanish" (and its feeling of belonging to a national territory and state) in addition to a regional identity or a local ethno-cultural-linguistic identity. There are the conflicting forces of the experience of an authoritarian unitary state before 1978, the very much larger language minorities (constitutionally recognised and protected: (Constitución Española 1978, Article 3), past separatism allied to terrorism, current separation attempts using quasi-legal or non-legal political means, and the constitutional recognition of the "peoples" (pueblos and nacionalidades) of Spain (Constitución Española 1978, Preamble and Article 2) within the imperative of "the indissoluble unity of the Spanish nation" (Article 2). In addition and as outlined, Vox presents a quasi-sacralised vision of the Spanish nation quite distinct from the constitutional and, as Vox sees it, fundamentally destructive framework of the State. For Vox, there is a total clash and it is this the national vision which must prevail rather than the constitutional form.

\subsection{EU-European and Culturally European Perspectives of the Nation}

\subsubsection{The EU-European Perspective}

For both parties there are significant and comparable conflicts between national identity and EU membership. In their most fundamental form these stem from the recognition that EU membership means a curtailment of national sovereignty resulting from the transfer of sole decision-making responsibility in certain areas away from the nation state to the Commission, the European Parliament, and the EU courts. There is also awareness of the transfer of national decision-making in the area of human rights to the Council of Europe's ECHR. Given that for the AfD popular sovereignty is repeatedly defined as the foundation of both democracy and national identity (AfD 2017, Chapter 1), and that the nation state as inseparable from popular sovereignty is part of a shared European norm, the dimensions of the problem become clear.

The manifesto for the 2017 Bundestag elections issued by AfD (AfD 2017), particularly Section 1 "Defence of Democracy", as also its manifesto for the 2019 EP elections (AfD EP 2019), defend the concept of the supremacy of the nation and consequently contain serious reservations about the EU. Similarly, Vox's 100 medidas (Vox España 2018) expresses reservations about the EU, but in its EP manifesto (Vox España EP 2019) its posture is much more critical and its views broadly but very significantly coincide with those of AfD. The insistence, for example, that sovereignty is vested in the totality of the Spanish people (Vox España 2014, pp. 4, 6; 2019a) and the position of AfD that national/popular sovereignty, Volkssouveränität, is the overriding principle of all political organisation, thus depriving the European Union of legitimacy as it possesses no Staatsvolk (see Gould 2018), lead to fundamental questioning of the European Union. Consequently, either implicitly or explicitly the parties share the view that the foundational treaties of the EU grant too much power to the Union, and that Brussels is abusing this power. The EU should be a confederation of sovereign nation-states working in partnership. This would preserve the sovereignty and increase the role of the individual nations, which each party considers of paramount importance. This includes their total control, via the intermediary of their state, of movement across their borders and of immigration policy, with Vox demanding also the suspension of the Schengen arrangements. For AfD it implies, and for Vox it is explicit, that each country should be solely responsible for its bilateral relations. Both parties demand restriction of the role of supranational courts. Both parties insist also on restoration of preferential treatment towards their own nationals for employment or any form of social welfare payments; this principal of national preference should apply also to business entities. Each of these proposals is being made in order to restore what the parties see as the diminished power and specificity of their nation as expressed by the general will in its sovereign state. However, it is clear that each of the proposals is incompatible with EU principles.

The claims to re-establish the fundamental legitimacy and the guiding force of the sovereignty of the nation and the concomitant calls for reform of the fundamental structures of the European Union lead logically and explicitly to a possible future consequence if reform efforts should fail. The AfD 
explicitly envisions the possible withdrawal of Germany from the EU, or even the orderly dissolution of the Union and the substitution of a European Economic Community. For Vox the eventuality is couched in less specific terms, but it does express "the possibility of leaving supranational organisations which are contrary to the interests of Spain" (Vox España 2018, Item 99).

These positions in defense of the nation/the "sovereign people" against the harmful incursions of Brussels restricting the actions and protections of the Nation through the intermediary of its national state choose to ignore the fact that the preamble of the constitution of each country asserts that it was the will of the nation that the constitution be enacted and that each constitution explicitly authorises transfer of constitutional powers to international organisations (Grundgesetz Articles 23 and 24; Constitución Española Section 93). For both parties, the insistence on national sovereignty and national specificity override these constitutional provisions. Protection of the Nation is more important than any other consideration.

\subsubsection{The European Cultural Perspective}

For each of the two parties under discussion national identity is nested within European identity with no conflict between the two. In each case, also, use is made of concepts referring specifically to characteristics deemed to be shared nation-wide: For AfD it is (deutsche) Leitkultur (defining culture) and Heimat; for Vox it is hispanidad (Spanishness) and arraigo (rootedness) in the Spanish land and practices. Each of these clearly contains an element of nativism or essentialism, each of them also sees identity as anchored in the past and in a given territory. (Eigler and Kugele 2012) remark on the conjunction of memory and space for Heimat, but mutatis mutandis it is equally the case with arraigo and hispanidad. They combine elements of social and personal culture together with genetics in that Heimat refers to an individual's or group's origins in the people of a given geographical region which can be as small as a village or as large as a country. The term itself is immensely evocative and also problematic (Boa and Palfreyman 2000; Blickle 2002; Gebhart et al. 2007; Costadura and Ries 2016). Additionally, in an era first of unification and then of migration it can take on different configurations (Costadura and Ries 2016; Kronenberg 2018). The "defining culture" expressed by Leitkultur contains elements of culture in the sense of a complex of shared values and practices differentiating Germans from Others (particularly non-Europeans), but also linking them with shared Europe-wide practices and with values considered part of a common European heritage. Specifically mentioned are: Humanism, Christianity and its contributions to European civilisation and culture, freedom of religion, separation of religion and reason, separation of religion and the state, German constitutional values, female emancipation, and the German language (Pautz 2005).

Hispanidad, in addition to its geographical component, is explicit in its expression of membership in an ethno-cultural group. It covers many of the same elements of group and personal culture, essentialism and nativism as Heimat or Leitkultur, though, clearly, the Christian element is restricted to Roman Catholicism. Moreover, it covers practices and values rooted (see: Arraigo) in local or rural life. However, in addition it also pertains to the larger context of the Spanish-speaking world (Vox España 2018, Items 66 and 100; Aguirre 2018). Importantly, for Vox hispanidad strongly correlates with religion (Zapata-Barrero n.d., p. 150) and can imply or include an element of islamophobia or maurophobia (Zapata-Barrero 2006; Aguirre 2018), a phenomenon very evident in Vox's conceptualisation of Spanish identity (Aguirre 2018; Vox España EP 2019).

Importantly, for Vox the insistence on hispanidad is both complemented and reinforced by the attention given to European cultural identity in the long and strongly-worded Preamble to its manifesto for the EP elections (Vox España EP 2019). This preamble harshly criticises and opposes all and any EU trends, tendencies and legislation which impinge in any way on the national identity and sovereignty of any European nation. For Vox there is no contrast or contradiction between Spanish and European identity. Furthermore, there is a considerable and important overlap (though not total coincidence) with AfD's views of European identity to be found in its federal manifesto (AfD 2017) and EP manifesto (AfD EP 2019). Both emphasise the imbrication of national cultures in European culture and place 
considerable emphasis also on the particular significance of European culture: For Vox it is explicitly la Civilización por excelencia, while for AfD it is implicitly, but clearly, so. For both parties this culture is founded above all on Christianity and the heritage of classical thought and values; and anything that the EU might do which would restrict or reduce these features or national specificity is harmful. In the name of its insistence on the Christian foundations of European culture and values, Vox asserts that "political deals" and "ideological prejudices" have contributed to the current crisis and "have built a Europe alienated from its spiritual foundations". More specifically, this is because of the influence of political postulates and practices of the Left and Social Democracy. For AfD the explicit rejection arising from the Christian foundation of the shared European culture is not of the Left, but of Muslim, and therefore Turkish, culture. This is parallel to the implicit element of Islamophobia perceptible in hispanidad (see above and Zapata-Barrero 2006; Aguirre 2018) and Vox's explicit rejection of Turkish EU membership (Vox España EP 2019, p. 9).

\subsubsection{Social and Familial Relationships as Producers of National Identity}

The traditional family is presented as providing a stable foundation for society as a whole and for its ability to prosper. It thus contributes to cohesion and to individuals' and the group's identification with the national territory.

Above all it is to be noted that the views of these relationships are distinctly conservative in nature and in the case of each party appear closely related to a vision of society as it existed before the pressures arising from globalisation and its resultant migrations, the migrations due to war and global inequalities, population movements within the EU, increasing secularisation throughout Europe and the shifts in social values of the late-twentieth and early twenty-first centuries, including those concerning marriage and women's participation in the workforce. Further information on the insecurities resulting from these changes, particularly in respect to the AfD and Germany but also generally, is to be found in (Gould 2018) drawing on (Beck 1997, 2000; Giddens 1991), and also in (Kenny 2017) who outlines the importance of nostalgia in current populist discourse. The parties are thus promoting the reassurance of the familiar, hence the appeal of everything that is implied in deutsche Leitkultur or Heimat on the one hand, and hispanidad or arraigo on the other, including the hint of superiority and the importance of Christianity in the first concept of each pair. At the same time, the use of these concepts has the important function of anchoring the individual within the national group and the territory which is the chief expression and locus of all these qualities.

\subsubsection{Marriage and the Family}

In both countries the family stands under the particular protection of the state (Grundgesetz 2019, Article 6; Constitución Española 1978, Article 39), and while admitting the existence and legitimacy (though grudgingly) of same-sex unions, both AfD and Vox ascribe a particular importance and function to the "classical" or "traditional" family of mother-plus-father-plus-children (AfD 2017, Willkommenskultur für Kinder; Vox España 2018, Section Vida y familia). As will be shown, because of the importance of family within the area of national identity and its position within country and state, it is to be promoted by a range of social and fiscal policies to encourage natality and support larger families (Vox España 2018; Vox España 2019a, Section 'Vida, familia e igualdad'; AfD 2017, chp. 7). For both parties the importance is national as well as social. The national element is paramount because of the concept, prominent in statements by both parties, that sovereignty lies respectively with the German or Spanish nation (AfD 2017, Section 1.1; Vox España 2018, Section 1 'Spain, Unity and Sovereignty'; Vox España 2014, Item 2).

This locus of sovereignty is not a peculiarly German or Spanish phenomenon, but is stated to be Europe-wide and an important positive characteristic of Europe and its culture as a whole, being a sine qua non of democracy (AfD 2017, 1.1) or of freedom (Vox España 2018). The weight of this view of the importance of the National is increased given the pragmatic situation in Spain of significantly increased (im)migration resulting from Europeanisation and globalisation, excess of 
deaths over births within the population as a whole (sometimes referred to as a "demographic winter": (Vox Andalucía 2019; PP 2019), plus a significant proportion of births being to resident foreign women (INE 2019a, p. 12), together with the fact that the population is rising only because of immigration (INE 2019b). In Germany the pattern is similar (though with a marginally increasing population), with a low birth rate, predominance of immigration over emigration, excess of deaths over births (Statistisches Bundesamt 2018). Inevitably, this results in a reduction of the proportion of the constitutive sovereign nation (Staatsvolk) within the population as a whole, presented in the case of AfD as a matter of particular and explicit concern (AfD 2017, 7.1 and 7.7), and in Vox with its "strong support" for large families (Vox España 2018, Item 72) and proposals for family allowances for "Spanish families" with dependent children (Vox España 2018, Item 73) and its insistence on the importance of reducing immigration (Vox España 2018, Section "Inmigración"). This maintenance or increase in what AfD calls "unsere angestammte Bevölkerung" (our native population) (AfD 2017, Section 7 "Welcoming Culture for Children, Encouraging Families, and Population Trends) is necessary in order for the constitutive nation, thought of in ethno-cultural terms, to maintain the highest degree of control over both the political process and national culture and values (Gould 2018; AfD 2017, Section 7). With Vox this matter is more implicit, but can be inferred from, for example, the importance attached to the family and the proposed measures to give support particularly to large families outlined earlier, and in the Manifiesto fundacional item 10 (Vox España 2014) and the role of folklore and traditions of Spain mentioned above.

\subsection{Religion and Language}

Within this perspective of social relations, the following subsection will now consider the roles first of religion and then of language.

\subsubsection{Religion: Islam versus Christianity}

The Christian foundation of the two countries and of Europe as a whole has already been outlined. Both parties see this as fundamental and inseparable from their respective societies and countries. On the other hand, in both Spain and Germany Christian religious observance is dropping noticeably (INE 2019c; Statistisches Bundesamt 2018). Within each country, however, there is the increasing presence of Islam, due principally both to labour-market immigration and to refugee movements

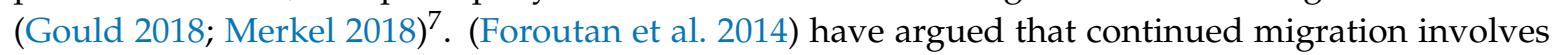
a social structural change. This element is then compounded when Islam is framed as an alien and harmful religion. In the case of Vox the saving of Spain and Europe from the Muslim invasion is viewed as a historic achievement and a mark of Spanish identity never to be forgotten (see above). The task of continuing the protection of Spanish society from the Muslim presence and particularly the Islamist threat has to be maintained (Vox España 2018, Section Defensa, seguridad y fronteras; Vox Andalucía 2019, Item 11). For the AfD, with its strong opposition to Islam arising from its insistence on deutsche Leitkultur which is based on the foundations of German culture, Christianity and Enlightenment values, the opposition is absolute and most clearly expressed in the manifesto for the 2017 federal election (AfD 2017; see also AfD EP 2019, Sections 6 and 8):

Civil Societies in functioning states are called upon to protect and develop their cultures on their own terms. This is naturally true for German cultural identity. The cultural and religious struggle [Kulturkampf] already being fought in Europe and the West between Islam [which is] a doctrine of religious salvation and vector of cultural traditions and legal obligations lying outside any possibility of integration can only be avoided by means of a 
set of defensive and restrictive measures which prevent further destruction of the European values of peaceful coexistence of enlightened citizens ${ }^{8}$.

Section 9.1 "German Defining Culture in the place of Multiculturalism"

In both cases, society and state can be maintained only through citizens' acceptance of a set of values which is, at least, culturally Christian and in opposition to Islam which is viewed as monolithically hostile to fundamental national and European cultural or religious values and traditions.

\subsubsection{Language}

Mentioned already in connection with the federal or federal-like structure of the national state is the question of subnational minorities. In Germany, which has very small native language minorities, this is not an issue. Danish and Sorbish have some local rights, but this is not felt to be in conflict with German identity. However, for AfD the German language itself holds a central place for identity and identification with country. As outlined in (Gould 2018, 16f) the language and its local variations are marks of German identity to be protected from foreign influences, particularly the use of English in education and administration and the impact of the (for AfD) negatively-connotated "gender ideology" which pushes to remove linguistic forms which mark human gender. The strong resistance to these influences is the result of the conviction that "the national language is the heart of a Kulturnation" (AfD 2017, Section 9.2; AfD EP 2019, Section 12.9). Kulturnation is a term widely used in German political and other statements to refer, among other things, to the German people's (and state's) possessing a common culture including a widely admired "high culture" of internationally-recognised artistic value.

Fundamentally, Vox shares this same position with respect to Spanish and this creates a very real social problem. For them the importance of Spanish as a unifying factor in the face of "the other Spanish languages" (see below) cannot be overstated. Article 3 of the Spanish Constitution determines that "Castilian is the official Spanish language of the State [i.e., of the country as a whole and of the national government]. All Spaniards have the duty to know it and the right to use it". The same Article then continues, "The other Spanish languages shall also be official in the respective Self-governing Communities in accordance with their Statutes" (Constitución Española 1978, Official English Translation). The Balearic Islands, the Basque Country, Catalonia, Galicia, Navarre and the Valencian Community have used this article to grant co-official status to their regional language(s) within all or part their territory. The same communities have also used their powers to make their own, differing, arrangements for the use of their language(s) in educational, administrative, and judicial matters.

For Vox, just like the existence of autonomous regions, this situation is incompatible with their vision of national identity and the State: To provide peace, order and good government, and as a sound foundation for community and identity, Spanish society has to have de facto only one language free to be used in all circumstances. In the name of national identity and unity the party wishes (a) to give protection to Spanish, "the shared language of everyone" (la lengua común de todos), from denigration or discrimination by any individual or public body, and (b) insists that a knowledge of Spanish alone shall be sufficient to hold any civil service position (Vox España 2018, Item 4). It is important to note that such proposals are tantamount to an attack on local identities above all in the north of Spain, where the three regional languages with co-official status, Galician, Basque, and Catalan, are solely or principally located. At the same time, given that very many schoolteachers are civil servants, if implemented, the measures would undermine the present and future of the languages by weakening their teaching of one or the other of their co-official languages, or their use as vehicular languages of instruction. Along with this, the party insists that throughout the country there be

8 For a comment and analysis of this argument see (Gould 2018, p. 36). 
created a right to receive schooling in Spanish and that parents alone (rather than legislation by the autonomous communities) have the right to determine the language of education of their children (Vox España 2014, p. 8; Vox España 2018, Item 62; Vox Andalucía 2019, Item 9).

Additionally, just as AfD defines Germany and Germans as a Kulturnation as part of definition and identification with territory, so for Vox the cultivation of cultural events, including high culture (Vox España 2018, Item 66; Vox España 2014, p. 1; Vox España EA 2019, Item 35), is a desideratum in the ongoing insistence on the importance and manifestation of national specificity against the current impact of other cultures and the ideas of a multiculturalism which is allegedly bent on robbing Europe of its identity and awareness of its past (Vox España EP 2019, Introduction "En Europa por España"). At the same time, insistence on the Spanish language reinforces the link to a glorious past (see above), hispanidad, the role that Spain played in world history, and the desire to extend its contemporary influence in international affairs through connections with the Spanish-speaking world (Vox España 2018, Item 100; Vox España EP 2019).

The following table (Table 1) provides an overview of the parties' positions on their respective nation and its identity:

Table 1. An overview of the parties' positions on their respective nation and its identity.

Alternative für Deutschland
National Identity Is Threatened
National identity is:
(a) Closely associated with the Constitution, but also cultural
(b) closely associated with Europe-wide cultural values,
including Christianity
(c) contrasted with Islam and strongly rejects Islam
(d) closely associated with the traditional family, including
for reasons of natality, hence rejection of (feminist)
in society
(e) expressed by the national language (German), and
consequently it must be protected and promoted
(f) closely associated with values summarised in deutsche
(g) heitkultur and Heimat

Emphasis on unrestricted popular sovereignty of the ethno-cultural nation as the locus of democracy, consequently:

(a) Hostility to EU because of limitations resulting from encroachment by the existing treaties

(b) call for new treaties which respect national sovereignty; failing that-Dexit

(c) national courts to be free of supranational oversight

(d) advocates the introduction of important elements of direct democracy at the national level

(e) advocates other measures to reduce party control

(f) call for total national control of borders and immigration

(g) national preferences to be re-introduced in the areas of social and economic policy VOX España

National Identity Is Threatened

National identity is:

(a) Above all pre-Constitutional, and also cultural; the Constitution has a fundamental flaw

(b) closely associated with Europe-wide cultural values, including Christianity

(c) contrasted with Islam and strongly rejects Islam

(d) closely associated with the traditional family, including for reasons of natality, hence rejection of (feminist) "ideologies" which promote changes in women's position in society

(e) expressed by the national language (Spanish only) and consequently it must be protected and promoted

(f) closely associated with values summarised in hispanidad and arraigo

(g) high culture and local culture

Emphasis on unrestricted popular sovereignty of the ethno-cultural nation as the locus of freedom, consequently:

(a) Hostility to EU because of limitations resulting from encroachment by the existing treaties

(b) call for new treaties which respect national sovereignty; failing that-Spexit

(c) national courts to be free of supranational oversight

(d) NIL

(e) NIL

(f) call for total national control of borders and immigration

(g) national preferences to be reintroduced in the areas of social and economic policy

All threats and problems outlined above result from the dangerous incompetence and corruption of the old-line parties (including their interactions with the EU and acceptance of EU practices and policies)

All threats and problems outlined above result from the dangerous incompetence and corruption of the old-line parties (including their interactions with the EU and acceptance of EU practices and policies)

Rejection of regional separatism, and explicitly that of Catalonia

\begin{tabular}{ll}
\hline Acceptance of the federal structure of the national state & $\begin{array}{l}\text { Total rejection of the quasi-federal structure of the national } \\
\text { state: the aim is recentralisation }\end{array}$ \\
\hline $\begin{array}{l}\text { No position on minority languages recognised at the state level } \\
\text { (Danish; Sorbish) }\end{array}$ & $\begin{array}{l}\text { Significant restrictions on the use and position of co-official } \\
\text { languages (Basque; Catalan; Galician) }\end{array}$ \\
\hline Absence of territorial claims & Call for return of Gibraltar to Spain \\
\hline
\end{tabular}




\section{Performing Crisis}

It has long been acknowledged that far-right and far-right-populist discourses of national identity include the assertion that the national group is endangered by a 'crisis' (Laclau 2005; Pirro and Taggart 2018). This may have internal or external origins, be political or economic, social, cultural, linguistic, have a long or short time-horizon, result from one or several 'enemies' including local elites. The revealing part of the crisis presentations of Vox and AfD is that each incorporates several dimensions: The political, the social, the economic, the cultural, the linguistic, the short-term, the long-term. Common to both discourses is the European Union, presented as responsible for restriction of popular and national sovereignty and attacks on revered cultural values including a conservative view of the family and gender identity. Similarly, there is the question of Muslin immigration. Shared responsibility is attributed also to the existing parties which have permitted and even promoted these phenomena. The old-line parties are unfit to govern in the two important senses that they are principally focused on their own advantage: Ensuring their control over the mechanisms of government to maintain themselves and their acolytes with steady and lucrative employment and, as is widely and publicly acknowledged in Spain, outright corruption at all levels including purely personal financial advantage as distinct from the party's financial advantage (Gómez Reino and Llamares 2019; Hawkins et al. 2019). In each case the new right-wing party, unburdened with either legacy policies or any history of political concessions, nor with any past opportunity to become corrupt, presents itself with stern warnings and stern measures as the saviour of country and national unity.

The paper will now turn to the question of the performance of crisis as the central element of each of the parties' communication strategies to transmit their views of national identity. In Section 2, Outline and Methodology, the paper introduced Moffitt's view of the importance of crisis as a fundamental part of populist style and his six-step model as a framework of analysis. This arose in connection with his view of the increasing mediatisation of politics (Moffitt and Tormey 2014) in the modern world. It appears that he and his sources were thinking of media in the more traditional sense of radio, television, and press. However, in addition to these, the expanding range of social media is now being extensively and intensively used for political communication by parties, groups, and individuals. Consequently, this section will also advance the view that rapid technological developments have made possible a more intensive performance of crisis than Moffitt might have envisioned.

The six points of Moffitt's framework are:

1. Identify failure.

2. Elevate the level of crisis by linking into a wider framework and adding a temporal dimension.

3. Frame 'the people' versus those responsible for the crisis.

4. Use media to propagate performance.

5. Present simple solutions and strong leadership.

6. Continue to propagate crisis.

The parties' practices on the fundamental question of national identity are the following:

1. Identify failure.

Both parties insist on their conviction that their nation and country are ill-served by current domestic political and international arrangements. The situation is so dire that the future existence of both nation and country in any way identifiable as wholly "Spanish" or "German" can no longer be presumed to be guaranteed. This represents a broad and monumental failure in multiple areas by the old-line parties of government.

2. Elevate to the level of crisis by linking into a wider framework and adding a temporal dimension:

This situation exists not only on the national dimension but also at the European level. Europe's fundamental political structure of nation states and its Christianity-based social and familial cultures and its sovereign-nation-state-based national identities are equally threatened by the same 
political incapacity to deal with recent-past, current, and foreseeable-future threats at the national and Europe-wide levels. The problem is so grave that immediate action is essential; no short-term solution is possible; only concerted and radical action will bring relief and remedy.

3. Frame 'the people' versus those responsible for the crisis:

Both nations are the victims of their professionalised political classes who use their positions of power for selfish ends, rather than listening to the voices of the people. Vox España frames itself as the voice of the overlooked honourable, honest, virtuous common man and woman (Abascal 2018), while (Butterwegge et al. 2018, p. 35) consider the selection of the name Alternative for Germany to be "optimal or even a stroke of genius", appealing to those who feel themselves overlooked and who desire an alternative politics. In addition, the old-line parties have made possible the Muslim presence in each country and in Europe in general, contrary to the wishes and interests of the people and contrary also to fundamental European civilisational values.

4. Use media to propagate performance:

Each of the parties is well aware of the need to use all means of communication as effectively and frequently as possible. This includes the traditional media and social media.

A confidential AfD strategy paper drawn up in preparation for the German state and federal elections in 2017 emphasises that the party "must be consciously, calculatedly and repeatedly politically incorrect" [underlined in the original] "and not be afraid of carefully planned provocation" (AfD 2016, pp. 10-11). It adds "The more they [the old-line parties] attempt to stigmatise the AfD for its provocative words or actions, the better that is for the image of the AfD" [also underlined in the original]. Not only will it distinguish the AfD from old-line parties, but the reactions will get media coverage beyond that accorded to the original AfD activities themselves. The analysis by (Schroeder et al. 2017) of social media accounts of AfD members of state parliaments shows that by the date of the strategy paper just mentioned AfD online activity was already well established. Developing ideas first outlined in 2016, (Vowe 2016, 2017) even concludes not only that the rapid rise of AfD would not have been possible without the existence of social media, but that this party knew better than any other in Germany how to manipulate opinion and determine the topics of talkshows (very popular in Germany) and editorials. He concludes that successful communication via text messages is now essential for the success of a populist party. Citing a range of scholarly sources, (Diehl et al. 2019) draw attention to the extreme activity of AfD on the web, particularly Facebook, and emphasises the influence AfD is able to exercise in this way. (Ruhose 2019, p. 16) concludes that the AfD's behaviour and use of language in its first year in the Bundestag is a "success story" and that they will continue to use "polarising statements, provocation and emotion" as a fundamental strategy. AfD has grasped the value of provocative utterances and actions to continue getting attention in the public at large. Additionally, just as Vox is benefitting from fake Twitter (and other) accounts which it may or may not have promoted (see below), AfD is known to be directly instrumental in the creation of such accounts, postings and re-tweets, etc., in order to promote its views and also individual AfD politicians (Reuter 2017, 2019). In addition, persons with a high profile in the AfD organisation tweet seemingly in their own name and in a more provocative manner than might be possible from the party account. A particular example of this was the case of Beate von Storch's harsh comments about Arab men in 2017. This enabled the party's Islamophobic and xenophobic views to be widely repeated in the traditional media without the party itself being directly accountable (Butterwegge et al. 2018, p. 341).

Vox grasped equally by the end of 2018 and beginning of 2019 the importance of provocation. It is quite clear that a number of the proposals in 100 medidas are extreme and the proposed abolition of the autonomous communities and transfer of powers to the central government would represent a radical change in the way Spain is governed, so radical in fact that the constitutional changes could not in reality be achieved (Castillo 2019). After the 2 December elections in Andalusia, Vox had the votes the PP needed to form a government. It submitted to the PP a public set of proposals representing their 
negotiating position. Many of the radical claims made at the national level, as well as some others, are contained in the document Propuestas de Vox para la investidura del presidente del gobierno de Andalucía (Vox Andalucía 2019). They are extreme in the sense that it was known in advance that they could not be realised in the then-current political context (and some of them probably never). In addition to stating the party's views, they are there also to provoke, and to provoke in such a way that they ensure media coverage and thus create free publicity. Particularly the proposals contained in Items (16) to (18) to repeal the Act to prevent Violence against Women (16), the Act to guarantee the Rights of Equality of Treatment and Non-discrimination of LGBTI Persons and their Families (17), and the Act to promote the Equality of the Sexes (18) provoked very large demonstrations throughout both Andalusia and Spain in mid-January 2019 when the new Andalusian Parliament met for the first time, and received significant media coverage (Valdés and Mora 2019).

Although (as yet) there appears to be no scholarly analysis of Vox's continuing use of social media (the ISD report The Great Replacement (Davey and Ebner 2019) mentions Vox just five times and deals only with the Andalusia campaign) two things emerge very clearly from investigations and reports in the quality press. Firstly, Vox has used and continues to use social media intensely; secondly it keeps the messaging clear and simple, repeating the fundamentals of its positions: Islamophobia, Catalan separatism, the no doubt Bannon-influenced España lo primero (Spain first) or hacer a España grande otra vez (Make Spain great again), and opposition to "feminist ideologies" always presented as totally opposed to traditional Spanish values. (Applebaum 2019) comments on the success of the tweets of two leading figures of Vox (Rocío Monasterio and Iván Espinosa) in putting on a show to get attention. However, in this they are repeating the strategy of Abascal himself. His Twitter account, for instance, contains a stream of tweets with images showing him in rooms full of followers (or noting that many people could not get in) in different parts of the country (the locations are always specified) with comments repeating the party's basic positions and/or denigrating political opponents (Abascal 2019). At the same time, (Peinado 2019) cites a report by the Institute for Strategic Dialogue in London that a network of nearly 3000 fake twitter accounts was sending Islamophobic messages and/or messages in support of Vox, particularly during the election campaign in the spring of 2019. Vox cannot be unaware of this, but one can reasonably assume that they are unconcerned. The fact that they are false is not significant; that they perform the crisis defined by Vox is. Cristina Monge of the University of Saragossa has pointed out that by means of such statements, and others, Vox succeeded in largely controlling the online news cycle just as Trump was doing at the same time. She refers to Lakoff's statement, "Trump uses social media as a weapon to control the news cycle. It works like a charm. His tweets are tactical rather than substantive. They mostly fall into one of these four categories": For example, pre-emptive framing, diversion, deflection, trial balloon (Lakoff 2018) (quoted in Rubio Hancock 2019).

The two Avaaz reports published in 2019, WhatsApp: Social Media's Dark Web (Avaaz 2019a) covering only Spain, and Far Right Networks of Deception (Avaaz 2019b) which analyses far-right Facebook networks in a number of European countries including Spain and Germany, reveal more of the extent of functioning networks not overtly associated with a party but which employ falsified information explicitly or implicitly to support policies or views of Vox or AfD, as the case may be. As noted above, WhatsApp is intensively used in Spain by the vast majority of smartphone subscribers, and the investigation indicated that $26 \%$ of persons entitled to vote had received such messages. It was Avaaz and not Vox which persuaded Facebook to take down offending networks five days before the elections on 28 April, arguing that they were contrary to company policy. Such messaging and sharing by individuals or groups in effect become part of the performance of crisis by the party in question: The diffusion and reinforcement of the view that the country is in a state of existential crisis which is threatening values held dear and which consequently endanger national identity.

It is clear that rapid electronic communication via the range of platforms now available is open to all parties without distinction and in ways which Moffitt could hardly envision when writing in 2014 for publication in 2015. However, it is also clear that the existence of instant transmission of text, image 
and sound facilitates performance of crises in the way that he conceived it: It enables the cost-free and rapid spread of focused and developing information in the categories mentioned, without the party itself having to be directly involved further. Spain has more mobile phones than inhabitants (Statista 2019b), 90\% of whom access WhatsApp from their phone (Statista 2019c). In Germany there are in 201961.5 million smartphone users (Statista 2019a). The party has only to provide the information of a particular provocative type around their basic themes which, in the case of both parties, are particularly concerned with the failure of traditional parties to defend and develop national identity. Provocation stimulates traditional media for the sake of circulation and revenue, but provocation by electronic media also stimulates individuals to be better integrated and better regarded by their peers in the communication of their ideas and ideals and feel themselves in touch with, and appreciated by, the party of their liking — without their having taken the formal step of joining (Gutiérrez-Rubí n.d.).

5. Present simple solutions and strong leadership:

With the new party statutes approved (Vox España 2019a) in an online vote before the party congress on 23 February 2019, Vox reinforced the centralisation of its structures conferring significantly more power on the President (Santiago Abascal) and the National Executive (the two are elected together) than under the old statutes (approved 18 October 2015; Vox España 2015). In fact, the candidate for president includes the eleven names of the National Executive in his candidacy (Vox España 2019a, Article 23). The new statutes also restrict voting rights of new members, abolish internal primary elections and provincial committees. This new structure also means that there are no formal structures at the municipal level or that of the autonomous communities. This, apparently, was done as a reaction to the tenfold rise in membership to 36,000 in the preceding year and ensures that Abascal can maintain his centralised control over the party (González 2019). In the same line of thinking, Vox stated that these changes were being made in order to guarantee that its message did not change in the face of changed circumstances (Vox España 2019b).

As already noted above, AfD has been the most successful German party in the use of electronic media for the propagation of its views on the crises of German identity and proposals for solutions. In this it has been helped by the staggered electoral system in Germany, where states hold their elections at different dates. This permits repetition or adjustment of messages, concentration on certain geographical areas as required, and development of communication techniques and strategies. The presence of the party in the EP, in local councils and three state parliaments (Saxony, Thuringia, and Brandenburg) since 2014 and then in other parliaments in the following years until by 2018 the AfD was represented in the Bundestag and all state parliaments, promoted this process. Parliamentary membership and the increased vote also provided significant funding from legitimate public sources. In addition, the elected representatives used the platforms provided to propagate their views on problems and solutions (Butterwegge et al. 2018; Schroeder et al. 2017), frequently in a provocative manner, as laid out in the confidential AfD strategy document for the 2017 election where members are enjoined "to be repeatedly politically incorrect" (AfD 2016, p. 10).

On the other hand, past splits within the party on ideological, personal, and regional lines (Butterwegge et al. 2018) including high-level resignations (Spiegel Online 2017), and the fact that AfD currently has two party chairmen (Alexander Gauland and Jörg Meuthen) undermine any claim that AfD has a single strong leader. In July 2019 Meuthen's criticism of the extreme nationalist position of the regional party president in Thuringia, Jörn Höcke, resulted in the former being rejected by the base in his home county (Kreis) as a delegate to the party congress in November 2019 (FAZ 2019). As this indicates, there is no central coordination in AfD's functioning at the local level, nor is there such coordination between state and federal parliamentarians (Butterwegge et al. 2018, p. 95). Notwithstanding that, and the existence of organised units at the state level—Landesverbände-(a very different organisational structure from that of Vox), AfD consistently maintains its position on the crisis resulting from the serious harm done to national identity and the need rapidly to repair this harm by redefining the relationship with the EU, reforming the EU, weakening the parties' hold 
over the legislatures and shifting more power to the sovereign people by increased use of referenda (see above). Importantly, this question of German identity with its strong nationalist overtones and strong rejection of Islam is the central message which holds the disparate trends and wings in the party together (Butterwegge et al. 2018, p. 64).

The pressures to speak bluntly and provocatively by party officials or ambitious party members on the topic of the nation and its identity emerge from the example cited above of the rejection of one of the party's national co-chairmen by his local party association. In this connection a highly relevant general comment has materialised from within the party. An individual who left the AfD has stated, "The base likes blunt talk as they see it as proof that they [officials and ambitious party members] have not been 'bent out of shape' and 'have remained true to the cause'. This means that that candidate gets elected who has the strongest polarising effect. If you speak moderately you make yourself suspect" (Quoted in Butterwegge et al. 2018, p. 348). Within the party, also, performing crisis pays, thus ensuring the continuation of the practice.

As outlined above, the solutions proposed by Vox to the social and political challenges of modern Spain are very simple, direct, and constantly repeated: They are contained in the first ten items of 100 medidas (Vox España 2018): (1) Suspension of Catalan autonomy, (2) banning of separatist parties and organisations, (3) providing maximum legal protection to national symbols, (4) no discriminatory measures against the Spanish language, (5) suppression of the police forces of the autonomous communities, (6) abolition of the autonomous communities, (7) increase of diplomatic pressure for the return of Gibraltar to Spain, (8) creation of an integrated plan for making better known the Spanish contributions to world history, (9) repeal of the Act concerning Historical Memory, and (10) abolition of the special financial and fiscal arrangements with the Basque Country and Navarre. Most of these would, in fact, be very hard, if not quite impossible, to achieve (see, for example, (Castillo 2019)). However, nuance is not provocative, does not stimulate media attention, re-tweeting, WhatsApp group conversations, forwards, etc. and the party knows that. By the end of 2018, i.e., at the start of the important series of elections throughout Spain, Vox had become the Spanish party reaching the most people via electronic communication, and using short sharp statements to propagate their fundamental message on Catalonia, Muslims, protection, and love of country (Viejo 2018).

6. Continuing crisis propagation:

This means remaining constantly active, maintaining communication on chosen fundamental themes, remaining provocative, and providing rapid reactions to events of the day. At the current time this implies intense use of social media and exploitation of the traditional media's need to report on political matters. On the supply side, none of the factors underlying the two parties' conservative visions of national identity will disappear in the near future. This, together with the fact that the solutions proposed are largely unrealisable (the lack of success can be blamed on the old-line parties) plus the additional fact that political communication (and particularly that of populist parties) is no longer dependent on print media or broadcasting, which are largely outside the new parties' control, means that the continuing performance of crisis propagation will remain a permanent and important part of the communication by Vox España and Alternative für Deutschland of their views on national identity.

\section{Conclusions}

The previous sections have outlined the important parallels in the positions on national identity of the two parties under discussion. In an overview of papers presented at a roundtable with the theme "Why has Nationalism not run its Course"? (Harris 2016) speaks of three particular triumphs of the contemporary nation-state: National identity, sovereign statehood, and democracy. It is instructive to consider briefly these three concepts in the light of the positions of AfD and Vox which view all three as being in a situation of crisis. In addition, the three are inseparable from each other, and the parties state that their aim is to preserve them from forces which are equally inseparable from the 
contemporary world: Migration (leading to population diversity), supranational political organisations, and economic Europeanisation/globalisation. (Pirro et al. 2018) have spoken of the frames by which populist Eurosceptic parties view and present European crises; this paper has extended this model also to the right-wing Vox in Spain.

The importance given by the parties to notions of language, culture, ancestry, descent (all relating to a mythical or admirable past which is extended into the present) are to be found in Heimat, arraigo, hispanidad, deutsche Leitkultur and are fundamental for their view of national identity. They demonstrate the backwards step away from any idea of the nation as a constructed community or community of choice à la Hobsbawm or Anderson. The parties present their Volk or nación as a homogenous ethno-cultural nation and in dire need of protection. This ethnic participation to the maximum extent possible in political decisions at the nation-state level is the guarantee of democracy. It is also a characteristic Europe-wide phenomenon which functions within a set of European values, one important source of which is Christianity. All these factors mark a fundamental distinction from Islam and its middle-Eastern or African adherents living in Europe or moving towards Europe.

(Harris 2016) also writes that these nineteenth-century ideas of political organisation have created "a set of political references whose meaning is so deeply entrenched in people's consciousness that the absence of an effective alternative creates a near existential anxiety". This view is elaborated on by Hosking in one of the papers given at the roundtable which Harris is summarising (Hosking 2016). It is the absence of "an effective alternative" which is key in the two cases studied. As has been seen, Vox and AfD are at pains to emphasise that the alternative which appears to exist, the EU, is neither effective in its promotion of the wellbeing of the people, nor is it legitimate in its existence. This is because the people are the only legitimate source of sovereignty and there is no European sovereign people. In their eyes the Union's existence and development have weakened national sovereignty and therefore democracy. The EU is also, they argue, attempting to weaken national identity by propagating social values alien to ones anchored in tradition and Christianity, including the relationship of men and women, and the definition of the family.

The situation, then, is the following: In the view of each of the parties, the processes of Europeanisation (allowed and encouraged by incompetent or corrupt politicians) have created a crisis for their view of national identity and the nation state- a crisis which they set out ostensibly to combat, but in fact are exploiting and even extending in order to consolidate and develop their own influence by means of the continuing performance of crisis. Their view is in fundamental opposition to the conviction, developed by European states and by the European Union in the late twentieth century, of the urgent necessity of shared sovereignty and mutual responsibility in order to promote political, social, and economic wellbeing across a fractious and fractured European continent which is now also faced with the economic forces of globalisation. To promote and perform their view of the crisis of national identity the parties are using the technological achievements of the twenty-first century to attack the late-twentieth-century political and social achievements of the European Union in order to replace them with the nineteenth-century concept of the distinct ethno-cultural nation unrestrictedly sovereign in its own nation-state. For the two countries in question which currently define themselves as active and committed members of the European Union, this would mean a radical shift in national identity.

Funding: This research received no external funding.

Conflicts of Interest: The author declares no conflict of interest.

\section{References}

Abascal, Santiago. 2015. Vox, La Derecha. Libertad Digital. Available online: https://www.libertaddigital.com/ opinion/santiago-abascal/vox-la-derecha-74892/ (accessed on 6 May 2019). 
Abascal, Santiago. 2018. Transcripcion discurso Santiago Abascal en Vistalegre. 7 October. Generously Made Available by the Research Project Nacionalismo de estado de democracias multinacionales: el impacto de la Gran Recesión sobre la identidad nacional at the Universidad Pablo de Olavide. Seville: Universidad Pablo de Olavide.

Abascal, Santiago. 2019. Available online: https://twitter.com/Santi_ABASCAL/status/1110653766653698050 (accessed on 3 August 2019).

Abascal Conde, Santiago, and Gustavo Bueno Sánchez. 2008. En defensa de España: Razones para el patriotismo español. Madrid: Asociación para la Defensa de la Nación Española y Ediciones Encuentro.

Acha, Beatriz. 2019a. Vox no es un partido (neo)fascista. Agenda Publica. January 6. Available online: http://agendapublica.elpais.com/no-no-es-un-partido-neofascista/ (accessed on 13 May 2019).

Acha, Beatriz. 2019b. La normalización 'exprés' de Vox. Agenda Publica. January 8. Available online: http://agendapublica.elpais.com/la-normalizacion-expres-de-vox/ (accessed on 18 May 2019).

AfD. 2016. Demokratie wieder herstellen. Dem Volk die Staatsgewalt zurückgeben. AfD-Manifest 2017. Die Strategie für das Wahljahr 2017. Confidential electoral strategy paper. Available online: http://www.talkrepublik.de/Rechtspopulismus/docs/03/AfD-Strategie-2017.pdf (accessed on 3 March 2019).

AfD. 2017. Programm für Deutschland. Wahlprogramm der Alternative für Deutschland für die Wahl zum Deutschen Bundestag am 24. September 2017. Available online: https://www.afd.de/wp-content/ uploads/sites/111/2017/06/2017-06-01_AfD-Bundestagswahlprogramm_Onlinefassung.pdf (accessed on 1 September 2017).

AfD Bavaria. 2018. Bayern. Aber sicher! Wahlprogramm Landtagswahl Bayern. Available online: https: //www.afdbayern.de/wahlen-2018/wahlprogramm-landtagswahl-2018/ (accessed on 1 June 2019).

AfD EP. 2019. Europawahlprogramm. Programm der Alternative für Deutschland für die Wahl zum 9. Europäischen Parlament 2019. Available online: https://www.afd.de/europawahlprogramm/ (accessed on 2 May 2019).

AfD Hesse. 2018. Hessen. Aber sicher! Wahlprogramm Landtagswahl Hessen. Available online: https://cdn.afd. tools/sites/179/2018/09/26103038/2018-08-23_LTW-HESSEN_FINAL_WEB.pdf (accessed on 2 May 2019).

Aguirre, Eduardo. 2018. España vive. Es una realidad que respira. Es una familia. Available online: https:// www.voxespana.es/opinion/espana-vive-es-una-realidad-que-respira-es-una-familia-20180924 (accessed on 4 December 2018).

Anduiza, Eva. 2018. El discurso de Vox. Agenda Publica. December 6. Available online: http://agendapublica. elpais.com/el-discurso-de-vox/ (accessed on 7 May 2019).

Anonymous. 2018. Vox. In La tentación populista española. Ikusle.

Applebaum, Anne. 2019. Los secretos de la estrategia de Vox. El País. May 11. Available online: https: //elpais.com/elpais/2019/05/10/ideas/1557485729_129647.html (accessed on 11 May 2019).

Arzheimer, Karl, and Carl Berning. 2019. How the Alternative for Germany (AfD) and their voters veered to the radical right 2013-2017. Electoral Studies 60: 102044. Available online: https://doi.org/10.1016/j.electstud.2019. 04.004 (accessed on 5 July 2019). [CrossRef]

Avaaz. 2019a. WhatsApp, Social Media's Dark Web: How the Messaging Service Is Being Flooded with Lies and Hate Ahead of the Spanish Elections. Avaaz.

Avaaz. 2019b. Far-Right Networks of Deception. Avaaz Report. Avaaz.

Baglioni, Sebastián. 2013. Multinational Democracy and Recognition in Spain 1978-2010. Ph.D. thesis, University of Toronto, Toronto, ON, Canada.

Bebnowski, David. 2015. Die Alternative für Deutschland: Aufstieg und gesellschaftliche Repräsentanz einer rechten populistischen Partei. Wiesbaden: Springer.

Beck, Ulrich. 1997. The Reinvention of Politics: Rethinking Modernity in the Global Social Order. Cambridge: Polity Press.

Beck, Ulrich. 2000. The Cosmopolitan Perspective. Sociology of the Second Age of Modernity. British Journal of Sociology 5: 79-105. [CrossRef]

Blickle, Peter. 2002. Heimat: A Critical Theory of the German Homeland. Rochester: Camden House.

Boa, Elizabeth, and Rachel Palfreyman. 2000. Heimat a German Dream: Regional Loyalties and National Identity in German Culture 1890-1990. Oxford: OUP.

Butterwegge, Christoph, Gudrun Hentges, and Gerd Wiegel. 2018. Rechtspopulisten im Parlament: Polemik, Agitation und Propaganda der AfD. Frankfurt: Westend Verlag. 
Casals, Xavier. 2016. La evolución de la ultraderecha en España: Claves Históricas y Territoriales. ARI 59/2017, 15 July. Madrid: Real Instituto Elcano.

Casals, Xavier. 2019. Aquí puede accederse a todos nuestros artículos sobre Vox. Available online: https: //xaviercasals.wordpress.com/2019/03/30/aqui-puede-accederse-a-todos-nuestros-articulos-sobre-vox/ (accessed on 26 April 2019).

Castillo, Pablo. 2019. Vox y la Constitución. El País. March 14. Available online: https://elpais.com/elpais/2019/03/ 12/opinion/1552413986_316642.html (accessed on 14 March 2019).

Constitución Española. 1978. Available online: http://www.congreso.es/portal/page/portal/Congreso/Congreso/ Hist_Normas/Norm/const_espa_texto_ingles_0.pdf (accessed on 4 August 2018).

Costadura, Edoardo, and Klaus Ries. 2016. Heimat, ein Problemaufriss. In Heimat Gestern und Heute: Interdisziplinäre Perspektiven. Edited by Edoardo Costadura and Klaus Ries. Bielefeld: Transcript, pp. 7-24.

Davey, Jacob, and Julia Ebner. 2019. The Great Replacement: The Violent Consequences of Mainstreamed Extremism. ISD Report. London: Institute for Strategic Dialogue.

Decker, Frank. 2016. The "Alternative for Germany": Factors Behind its Emergence and Profile of a New Right-wing Populist Party. German Politics and Society 34: 1-16. [CrossRef]

Die Welt. 2019. Eurowahlkampf: Die Bannon-Methode. Welt-Online: Welt am Sonntag. April 14. Available online: https:/www.welt.de/politik/ausland/plus191873301/Europawahlkampf-Die-BannonMethode.html (accessed on 27 November 2019).

Diehl, Jörg, Roman Lehberger, Ann-Katrin Müller, and Philipp Seibt. 2019. Warum die AfD auf Facebook so erfolgreich ist. Spiegel Plus. April 26. Available online: https://www.spiegel.de/plus/warum-die-afd-auffacebook-so-erfolgreich-ist-a-00000000-0002-0001-0000-000163612064 (accessed on 4 July 2019).

Eigler, Friederike, and Jens Kugele. 2012. Introduction: Heimat at the intersection of memory and space. In Heimat: At the Intersection of memory and space. Edited by Friederike Eigler and Jens Kugele. Berlin: De Gruyter, pp. 1-12.

El Confidencial. 2015. Newsletter 24-Mresultados. Available online: https://www.elconfidencial.com/eleccionesmunicipales-y-autonomicas/resultados-4/ (accessed on 13 May 2019).

FAZ. 2019. Frankfurter Allgemeine Zeitung. July 15. Available online: https://www.faz.net/aktuell/politik/inland/ machtkampf-in-afd-meuthen-erleidet-niederlage-16286233.html (accessed on 15 July 2019).

Foroutan, Naika, Cosgun Canan, Sina Arnold, Benjamin Schwarze, Steffen Beigang, and Dorina Kalkum. 2014. Deutschland postmigrantisch I: Gesellschaft, Religion, Identität. Erste Ergebnisse. Berlin: Berliner Institut für Empirische Integrations-und Migrationsforschung.

Gebhart, Gunther, Oliver Geisler, and Steffen Schröter. 2007. Heimatdenken: Konjunkturen und Konturen. Statt einer Einleitung. In Heimat: Konturen und Konjunkturen eines Umstrittenen Konzepts. Edited by Gunther Gebhart, Oliver Geisler and Steffen Schröter. Bielefeld: Transcript, pp. 9-56.

Geiges, Lars. 2018. Wie die AfD im Kontext der 'Flüchtlingskrise' mobilisierte. Eine empirisch-qualitative Untersuchung der 'Herbstoffensive 2015'. Zeitschrift für Politikwissenschaft 28: 49-69. [CrossRef]

Giddens, Anthony. 1991. Modernity and Self-Identity: Self and Society in the Late Modern Age. Cambridge: Polity Press.

Gómez Reino, Margaret, and Iván Llamares. 2019. Populism in Spain: the role of ideational change in Podemos. In The Ideational Approach to Populism: Concept, Theory and Analysis. Edited by Kirk A. Hawkins, Ryan E. Carlin, Levente Littvay and Cristóbal Rivera Kaltwasser. London and New York: Routledge, pp. 294-310.

González, Miguel. 2019. Abascal blinda su poder en Vox ante el temor a perder el control del partido. El País. February 22. Available online: https://elpais.com/politica/2019/02/22/actualidad/1550868087_012611.html (accessed on 22 February 2019).

Gould, Robert. 2018. Culture and Constitution: An Alternative Identity for Germany. Working Paper for Demospain, Universidad Pablo de Olavide, Seville. Available online: https://www.upo.es/ investiga/demospain/wp-content/uploads/2018/11/2018.10.22_DT.Demospain_2018.003.pdf (accessed on 4 December 2018).

Gould, Robert. 2019. Vox España, an Alternative Identity for Spain: Nationalism, Opposition to the European Union and Proposals for a "Spexit". Ottawa: Commentary Written for the Jean-Monet Centre of Excellence at Carleton University, Available online: https://carleton.ca/ces/wp-content/uploads/Commentary-Vox-An-AlternativeIdentity-for-Spain-by-Robert-Gould-February-2019-rev.pdf (accessed on 1 March 2019). 
Grundgesetz. 2019. Grundgesetz für die Bundesrepublik Deutschland. Available online: http://www.gesetze-iminternet.de/gg/GG.pdf (accessed on 4 April 2019).

Gutiérrez-Rubí, Antoni. n.d. La politica en tiempos de WhatsApp. El País Libros, Kindle.

Hambauer, Verena, and Anja Mays. 2018. Wer wählt die AfD?_Ein Vergleich der Sozialstruktur, politischen Einstellungen und Einstellungen zu Flüchtlingen zwischen AfD-WählerInnen und der WählerInnen der anderen Parteien. Zeitschrift für Politikwisssenschaft 12: 133-54. [CrossRef]

Hansen, Michael A., and Jonathan Olsen. 2019. Flesh of the Same Flesh: A Study of Voters for the Alternative for Germany (AfD) in the 2017 Federal Election. German Politics 28: 1-19. [CrossRef]

Harris, Erika. 2016. Why has Nationalism not run its Course? Nations and Nationalism 22: 243-47. [CrossRef]

Häusler, Alexander. 2019. Forms of Right-Wing Populism: The Example Alternative for Germany. In Stifled Progress: International Perspectives on Social Work and Social Policy in the Era of Right-Wing Populism. Edited by Jörg Fischer and Kerry Dunn. Opladen, Berlin and Toronto: Verlag Barbara Budrich, pp. 17-32.

Hawkins, Kirk A., Ryan E. Carlin, Levente Littvay, and Cristóbal Rovira Kaltwasser, eds. 2019. The Ideational Approach to Populism: Concept, Theory and Analysis. Abingdon and New York City: Routledge.

Hosking, Geoffrey. 2016. Why has Nationalism revived in Europe?: The symbolic attractions and fiscal capabilities of the nation state. Nations and Nationalism 22: 210-221. [CrossRef]

Humlebæk, Carsten. 2015. Spain: Inventing the Nation. London: Bloomsbury.

INE. 2019a. España en Cifras 2019; Madrid: Instituto Nacional de Estadistica. Available online: https://www.ine.es/ prodyser/espa_cifras/2019/10/index.html\#zoom=z (accessed on 18 July 2019).

INE. 2019b. Cifras de Población (CP) a 1 de enero de 2019, Estadística de Migraciones (EM). Año 2018; Nota de Prensa. Madrid: Instituto Nacional de Estadistica, June 25. Available online: https:/www.ine.es/prensa/cp_e2019_p. pdf (accessed on 25 June 2019).

INE. 2019c. Movimiento Natural de la Población; Section Matrimonios 2008-2018 por Forma de Celebración Nota de Prensa. Madrid: Instituto Nacional de Estadistica. Available online: https://www.ine.es/prensa/mnp_2018_p. pdf (accessed on 4 July 2019).

Jahn, Joachim. 2013. Gründungsparteitag der AFD: Aufstand Gegen Merkels 'Alternativlose Politik'. FAZ. April 14. Available online: https://www.faz.net/aktuell/wirtschaft/wirtschaftspolitik/gruendungsparteitagder-afd-aufstand-gegen-merkels-alternativlose-politik-12148549.html (accessed on 1 August 2019).

Jesse, Eckhard. 2019. Das Aufkommen der Alternative für Deutschland: Deutschland ist kein Ausnahmefall mehr. In Rechtspopulismus in Einwanderungsgesellschaften: Die Politische Auseinandersetzung um Migration und Integration. Edited by Heinz Ulrich Brinkmann and Isabelle-Christine Panreck. Wiesbaden: Springer, pp. 97-131.

Junquera, Natalia. 2018. Qué Tienen en Común Vox, el jefe de la Campaña de Trump y Le Pen. El País. Available online: https://elpais.com/politica/2018/12/04/actualidad/1543949909_697562.html (accessed on 15 April 2019).

Kadner, Marién. 2014. Los viejos partidos se lo están gastando todo en las autonomías. El País. Available online: https://elpais.com/politica/2014/05/08/actualidad/1399572161_114854.html (accessed on 13 May 2019).

Kenny, Michael. 2017. Back to the Populist Future? Understanding Nostalgia in Contemporary Populist Discourse. Journal of Political Ideologies 22: 256-73. [CrossRef]

Kronenberg, Volker. 2018. Heimat Bilden: Herausforderungen, Erfahrungen, Perspektiven. Berlin and Sankt Augustin: Konrad-Adenauer-Stiftung, Available online: http://www.kas.de/wf/de/33.53340/ (accessed on 7 May 2019).

Laclau, Ernesto. 2005. On Populist Reason. London: Verso.

Lakoff, George. 2018. @GeorgeLakoff. Available online: https://twitter.com/GeorgeLakoff/status/ 948424436058791937/photo/1 (accessed on 5 July 2019).

Lecours, André. 2018. Nationalism and the Strength of Secessionism in Liberal-Democracies: Static and Dynamic Autonomy. Paper presented at Western Political Science Association, San Diego, CA, USA, April 18-20.

Lees, Charles. 2018. The 'Alternative for Germany': The rise of right-wing populism at the heart of Europe. Politics 38: 295-310. [CrossRef]

Lehmann, Pola, and Theres Matthieß. 2017. Nation und Tradition: Wie die AfD nach rechts rückt. WZB Mitteilungen Heft 156. Berlin: Wissenschaftszentrum Berlin, pp. 21-24.

Lengfeld, Holger. 2017. Die "Alternative für Deutschland": Eine Partei für Modernisierungsverlierer? Kölner Zeitschrift für Soziologie und Sozialpsychologie 69: 209-32. [CrossRef] 
Lengfeld, Holger, and Clara Dilger. 2018. Kulturelle und ökonomische Bedrohung. Eine Analyse der Ursachen der Parteiidentification mit der 'Alternative für Deutschland' mit dem Sozio-oekonomischen Panel 2016. Zeitschrift für Soziologie 47: 181-99. [CrossRef]

Lewandowsky, Marcel. 2016. Die Verteidigung der Nation: Außen-und europapolitische Positionen der AfD im Spiegel des Rechtspopulismus. In Die Alternative für Deutschland. Edited by Alexander Häusler. Wiesbaden: Springer, pp. 39-51.

Lux, Thomas. 2018. Die AfD und die unteren Statuslagen. Eine Forschungsnotiz zu Holger Lengfelds Studie Die "Alternative für Deutschland": eine Partei für Modernisierungsverlierer? Kölner Zeitschrift für Soziologie und Sozialpsychologie 69: 209-32. [CrossRef]

Merkel, Angela. 2018. Deutscher Bundestag, Stenografischer Bericht. March 21. Available online: http://dipbt. bundestag.de/dip21/btp/19/19022.pdf\#P.1811 (accessed on 1 August 2019).

Moffitt, Benjamin. 2014. How to perform Crisis: A Model for understanding the Key Role of Crisis in contemporary Populism. Government and Opposition 50: 189-2017. [CrossRef]

Moffitt, Benjamin. 2016. The Global Rise of Populism: Performance, Political Style, and Representation. Stanford: Stanford UP.

Moffitt, Benjamin, and Simon Tormey. 2014. Politics, mediatisation and political style. Political Studies 62: 381-97. [CrossRef]

Ortiz, Pablo. 2019. The electoral breakthrough of the radical right in Spain: explaining electoral support for VOX in Andalusia. Genealogy. forthcoming.

Pautz, Hartwig. 2005. The politics of identity in Germany: the Leitkultur debate. Race and Class 46: 39-52. [CrossRef]

Peinado, Fernando. 2019. Una red de cuentas falsas de Twitter promueva a Vox en campaña. El País. April 25. Available online: https:/elpais.com/politica/2019/04/25/actualidad/1556203502_359349.html (accessed on 25 April 2019).

Pérez Oliva, Milagros. 2018. Bannon y el bidón de gasolina. El País. September 14. Available online: https://elpais.com/elpais/2018/09/13/opinion/1536861342_054987.html (accessed on 16 April 2019).

Piñar Pinedo, Blas. 2015. Del PP a Vox: De la traición de Rajoy a la nueva derecha española. Edición Digital Amazon.

Pirro, Andrea L. P., and Paul Taggart. 2018. The populist politics of Euroscepticism in times of crisis. Politics 38: 253-62. [CrossRef]

Pirro, Andrea L. P., Paul Taggart, and Stijn van Kessel. 2018. The populist politics of Euroscepticism in times of crisis: Comparative conclusions. Politics 38: 378-90. [CrossRef]

PP. 2019. Nota de Prensa: Pablo Casado anuncia hoy una Ley de Apoyo a la Maternidad que abogue por la 'cultura de la vida'. Available online: https://www.pp.es/actualidad-noticia/pablo-casado-anuncia-una-leyapoyo-maternidad-que-abogue-por-cultura-vida (accessed on 11 March 2019).

Reuter, Markus. 2017. So Twittert Die AfD. Netzpolitik. Available online: https://netzpolitik.org/tag/so-twittert-dieafd/ (accessed on 17 July 2019).

Reuter, Markus. 2019. Fälschen, Züchten und Verstärken. Fragwürdige Twitter-Tricks bei der AfD. Netzpolitik. May 25. Available online: https://netzpolitik.org/2019/faelschen-zuechten-und-verstaerken-fragwuerdigetwitter-tricks-bei-der-afd/ (accessed on 17 July 2019).

Rubio Hancock, Jaime. 2019. Así intenta Vox marcar la agenda política en Twitter. El País. March 4. Available online: https://verne.elpais.com/verne/2019/03/01/articulo/1551440154_984811.html (accessed on 4 March 2019).

Ruhose, Fedor. 2019. Die AfD im Deutschen Bundestag: Zum Umgang mit einem neuen politischen Akteur. Wiesbaden: Springer Fachmedien.

Sarrazin, Thilo. 2010. Deutschland schafft sich ab: Wie wir unser Land aufs Spiel setzen. Munich: Deutsche Verlags-Anstalt.

Schroeder, Wolfgang, Bernhard Weßels, Christian Neusser, and Alexander Berzel. 2017. Parlamentarische Praxis der AfD in deutschen Landesparlamenten. Discussion Paper SP V 2017-102. Berlin: Wissenschaftszentrum Berlin für Sozialforschung.

Serrau, Marc Felix. 2019. Steve Bannon: "Nach der Wahl wird jeder Tag in Brüssel Stalingrad sein”. Neue Zürcher Zeitung. May 16. Available online: https://www.nzz.ch/international/steve-bannon-im-interview-bruesselwird-zu-stalingrad-ld.1481934 (accessed on 16 September 2019). 
Spiegel Online. 2017. AfD-Chefin Petry sorgt für Eklat. September 25. Available online: https://www.spiegel. de/politik/deutschland/frauke-petry-wird-afd-fraktion-im-bundestag-nicht-angehoeren-a-1169661.html (accessed on 3 June 2019).

Statista. 2019a. Number of Smartphone Users in Germany from 2015 to 2022 (in Millions). Available online: https: //www.statista.com/statistics/467170/forecast-of-smartphone-users-in-germany/ (accessed on 2 July 2019).

Statista. 2019b. Ranking de las principales redes sociales y de mensajería en España a fecha de abril de 2019, según el porcentaje de usuarios que accedió desde un smartphone. Available online: https:/es.statista.com/estadisticas/ 575784/acceso-a-las-principales-redes-sociales-por-smartphone-en-espana-por-red-social/ (accessed on 2 July 2019).

Statista. 2019c. Consumo y uso de smartphones en España-Datos estadísticos. Statista Research Department. July 26. Available online: https://es.statista.com/temas/4086/consumo-y-uso-de-smartphones-en-espana/ (accessed on 2 July 2019).

Statistisches Bundesamt. 2018. Statistisches Jahrbuch 2018. Kapitel 2 "Bevölkerung, Familien, Lebensformen". Available online: https://www.destatis.de/DE/Themen/Querschnitt/Jahrbuch/jb-bevoelkerung.pdf?_blob= publicationFile\&v=6 (accessed on 2 July 2019).

Taggart, Paul. 2000. Populism. Birmingham: Open University Press.

Turnbull-Dugarte, Stuart J. 2019. Explaining the End of Spanish Exceptionalism and electoral Support for Vox. Research and Politics April-June: 1-8. [CrossRef]

Valdés, Isabel, and Antonio Mora. 2019. Miles de mujeres contra Vox: ‘Nos tendrán enfrente si tocan nuestros derechos: El País, January 16. Available online: https:/elpais.com/politica/2019/01/15/actualidad/1547577004_ 626639.html (accessed on 16 January 2019).

Verdú, Daniel. 2019. Steve Bannon, exasesor de Donald Trump y uno de los padres del populismo, explica su relación con Vox y el asalto a Europa del grupo de partidos a los que aconseja. El País. March 24, pp. 4-5. Available online: https://elpais.com/internacional/2019/03/24/actualidad/1553454729_290547.html (accessed on 24 March 2019).

Viejo, Manuel. 2018. La estrategia de Vox en redes sociales: ya es el primer partido en Instagram, la plataforma con más jóvenes. El País. December 16. Available online: https://elpais.com/politica/2018/12/12/actualidad/ 1544624671_005462.html (accessed on 13 July 2019).

Vowe, Gerhard. 2016. Politische Kommunikation in der Migrationskrise: Der strukturelle Wandel der Kommunikation und die Herausforderung für Politik und Wissenschaft. Publizistik 61: 431-40. [CrossRef]

Vowe, Gerhard. 2017. Der strukturelle Wandel der politischen Kommunikation und seine Folgen für die Politik: Das Beispiel der Migrationsdebatte. Medien Journal 41: 5-21. [CrossRef]

Vox Andalucía. 2019. Propuestas de Vox para la investidura del Presidente de la Junta de Andalucía. Available online: https://www.voxespana.es/propuesta-de-vox-para-la-investidura-del-presidente-de-lajunta-de-andalucia (accessed on 9 January 2019).

Vox España. 2014. Manifiesto fundacional. Available online: https://www.voxespana.es/espana/manifiestofundacional-vox (accessed on 9 January 2019).

Vox España. 2015. Estatutos de Vox. Available online: https://www.voxespana.es/wp-content/uploads/2016/05/ ESTATUTOS-VOX-Aprobados-18-10-15.pdf (accessed on 15 July 2019).

Vox España. 2018. 100 medidas para la España Viva. Available online: https://www.voxespana.es/biblioteca/ espana/2018m/gal_c2d72e181103013447.pdf (accessed on 9 January 2019).

Vox España. 2019a. Estatutos. Available online: https://www.voxespana.es/wp-content/uploads/2019/05/ ESTATUTOS-VOX-23-02-2019.pdf (accessed on 15 July 2019).

Vox España. 2019b. VOX sale reforzado en la asamblea general del 23 de febrero. Available online: https://www. voxespana.es/vox-sale-reforzado-en-la-asamblea-general-del-23-de-febrero (accessed on 25 February 2019).

Vox España EA. 2019. Programa electoral para las elecciones autonómicas de 2019. Available online: https: //www.voxespana.es/programa-elecciones-autonomicas-2019 (accessed on 4 May 2019).

Vox España EP. 2019. Programa electoral para las elecciones europeas de 2019. Available online: https://www. voxespana.es/wp-content/uploads/2019/05/Programa-Europeas-2019_web.pdf (accessed on 12 April 2019).

Wodak, Ruth, and Michael Meyer, eds. 2009. Methods of Critical Discourse Analysis. London: Sage Publications.

Wodak, Ruth, Rudolf de Cillia, Martin Reisigl, Karin Liebhart, Klaus Hofstätter, and Maria Kargl. 1998. Zur diskursiven Konstruktion nationaler Identität. Frankfurt: Suhrkamp. 
Zapata-Barrero, Ricard. 2006. The Muslim Community and Spanish Tradition: Maurophobia as a Fact, and impartiality as a desideratum. In Multiculturalism, Muslims, and Citizenship. Edited by Tariq Modood, Anna Triandafyllidou and Ricard Zapata-Barero. London and New York: Routledge, pp. 143-61.

Zapata-Barrero, Ricard. n.d. La política del discurso sobre la inmigración en España. In El discurso político en torno a la inmigración en España y en la UE. Edited by Ricard Zapata-Barrero, Elisabet González and Elena Sánchez Montijano. Documentos del observatorio permanente de la inmigración. Madrid: Ministerio de Trabajo e Inmigración, pp. 17-160. Available online: http://extranjeros.mitramiss.gob.es/es/ObservatorioPermanenteInmigracion/Publicaciones/ fichas/archivos/El_discurso_polxtico_en_torno_a_la_inmigracixn_en_Espaxa_y_en_la_UE.pdf.pdf (accessed on 5 April 2017).

Zick, Andreas, Beate Küpper, and Wilhelm Berghahn. 2019. Verlorene Mitte-Feindselige Zustände: Rechtsextreme Einstellungen in Deutschland 2018/2019. Friedrich-Ebert-Stiftung Bonn: Dietz-Verlag.

(C) 2019 by the author. Licensee MDPI, Basel, Switzerland. This article is an open access article distributed under the terms and conditions of the Creative Commons Attribution (CC BY) license (http://creativecommons.org/licenses/by/4.0/). 